\title{
135 anos sem Marx: desafios para a esquerda mundial
}

135 anos sem Marx: desafios para a esquerda mundial é o tema que a revista Argumentum escolheu para este número em celebração aos 200 anos do nascimento de Karl Marx, homenagem que está sendo realizada em todos os países do mundo em artigos, livros, seminários, congressos e outros eventos. O texto principal, da seção Debate, foi escrito para este número da revista por um dos mais célebres e respeitado marxista, intelectual e militante de nossa época, o professor Samir Amin. Ele escolheu escrever sobre a atualidade de um dos livros mais conhecidos da literatura marxista: O Manifesto Comunista, de Marx e Engels, publicado pela primeira vez em 1848. O texto, O Manifesto Comunista 170 anos Depois, foi comentado pelo professor Andrés Piqueras Infante, da Universidade Jaume I de Castelló, Espanha, e pelo professor Smaïl Hadj Ali, das Universidades de Argel e de Haute Bretagne, na Argélia e na França. Todos escritos especialmente para a Argumentum.

Em 4 de agosto, fomos surpreendidos com a informação de que Samir teve que ser hospitalizado em Paris devido às suas condições de saúde e, no dia 12, uma terrível notícia: "Um baobab est tombé; le professeur Samir Amin est décédé cet après-midi à Paris", escreveu Cherif Salif Sy, um colaborador muito próximo de Samir há muitas décadas. Cherif foi um dos conferencistas presentes no 6을 Encontro Internacional e 13ํㅡㄹ Encontro Nacional de Política Social, em Vitória, no início de junho de 2018.

A triste notícia se espalhou como um rastilho de pólvora por todo o mundo, na imprensa e nas mídias sociais, destacando e homenageando a importância intelectual, acadêmica e militante de Samir. O prestigiado Le Monde Diplomatique publicou: "Crítico do eurocentrismo e teórico do altermundialismo, conselheiro de muitos governos do Terceiro Mundo e 'nãoalinhado', defendeu um mundo multipolar e uma Quinta Internacional. Ele dedicou sua vida a 'derrotar o projeto imperial"'. Em sua versão para a África o Le Monde anunciou que “depois de dedicar sua vida, seu trabalho teórico e sua práxis política a serviço dos países do Sul e sua emancipação do legado colonial, ele foi provavelmente o único economista do Terceiro Mundo estudado em universidades de todo o mundo". Até mesmo o Le Figaro, o segundo maior jornal francês, classificado como de direita, publicou uma nota a partir do anúncio feito pela agência de notícias France Press. O Le Figaro destacou a homenagem do Presidente do Senegal, MackySall, que escreveu em sua conta do twiter "Ele dedicou toda a sua vida à luta pela dignidade da África, pela causa do povo e dos pobres. Com o desaparecimento do professor Samir Amin, o pensamento econômico contemporâneo está perdendo uma de suas figuras ilustres". Não foi o único chefe de Estado, Samir Amin recebeu igualmente homenagens de Nicolás Maduro, da Venezuela, e de Evo Morales, da Bolívia. As incontáveis notas de tristeza e pesar, de homenagens e reconhecimento pelo seu trabalho, feitas por acadêmicos, políticos e militantes anticapitalistas de todo o mundo, principalmente através das mídias

\footnotetext{
1 “Um baobá caiu; o professor Samir Amin faleceu nesta tarde em Paris.”
} 
sociais, só enaltecem a importância intelectual do trabalho de Samir Amin. Neste editorial, a Argumentum registra e se soma a todas essas manifestações.

Samir foi fundador e dirigente do Fórum do Terceiro Mundo (FTM), sediado em Dakar, no Senegal, e também um dos fundadores do Fórum Mundial de Alternativas (FMA), junto com François Houtart. Para a academia, da África, o Conselho para o Desenvolvimento da Pesquisa em Ciências Sociais em África (CODESRIA), do qual foi o primeiro Secretário Executivo. A Argumentum deseja, igualmente, registrar uma longa trajetória e parceria com colaboradores muito próximos do Samir, alguns dos quais durante décadas, que honraram o Programa de Pós-Graduação em Política Social com suas contribuições como conferencistas em várias edições do Encontro Internacional e Nacional de Política Social e como autores da revista Argumentum. Entre eles podemos destacar François Houtart, Rémy Herrera, Wim Dierchxsens, Sam Moyo, Mamdouh Habashi, Lau Kin Chi, Victor Hugo Jijón, Valentin Yakushik e Chérif Salif Sy.

Gostaríamos em seguida de registrar o enorme legado intelectual, militante e teórico de Samir. Ele foi um dos primeiros economistas a defender que o sistema capitalista mundial produziu simultaneamente o Centro e a Periferia, os países desenvolvidos e subdesenvolvidos, o desenvolvimento e o atraso. Em uma entrevista concedida em 2003, para Nestor Kohan e Gabriela Roffinelli², ele conta que: “Quer dizer que fui um 'anti-Rostow'3, antes dele escrever [...]. Porque minha tese foi escrita quatro anos antes da publicação de seu livro. O desenvolvimento não consiste em etapas de longo prazo sobre um mesmo caminho percorrido. Em cada uma de suas fases, o capitalismo produz uma polarização, um contraste entre centros e periferias. O que sim é verdade é que o fundamento, a base sobre a qual se reproduz e aprofunda esse contraste, entre o centro e a periferia, não é o mesmo em cada uma das fases do capitalismo".

Ele foi também um dos primeiros a procurar integrar os intelectuais progressistas do Sul, sem esquecer seu estreito relacionamento na Ásia, particularmente com a China. Ele recebeu também a etiqueta de maoísta. Na mesma entrevista ele contava que: "De fato, tive a oportunidade de ser diretor do Instituto Africano de Desenvolvimento Econômico, a partir de 1971. Uma de minhas primeiras preocupações foi romper com o isolamento relativo em que o colonialismo tinha colocado a África em relação à América Latina e à Ásia. Então organizei dois encontros que foram os precursores. Um deles reuniu africanos e latinoamericanos. Aconteceu em Dakar, Senegal, em 71/72. Neste encontro participaram os latinoamericanos Fernando H. Cardoso, Octavio Ianni, Enrique Oteiza, Pablo González Casanova, Theotonio dos Santos, Ruy Mauro Marini, Maria da Conceição Tavares, entre muitos outros”. Os leitores de Argumentum devem reconhecer que a maioria consta em suas leituras obrigatórias.

\footnotetext{
${ }_{2}^{2}$ AMIN, Samir. He sido y sigo siendo comunista. [Entrevista cedida a] Gabriela Rofinelli e Néstor Kohan. La Haine, 27 set. 2003. Republicado em 15 de agosto de 2018 por ocasião do falecimento de Samir Amin. Disponível em:

<https://www.lahaine.org/mundo.php/samir_amin_he_sido_y_sigo_siendo_comunis $>$. Acesso em: 15 ago. 2018.

3 ROSTOW, Walt W. Etapas do desenvolvimento econômico. (Um manifesto não-comunista). 2. ed. Rio de Janeiro: Zahar, 1964.
}

Argum., Vitória, v. 10, n. 2, p. 4-6, maio./ago. 2018. 
Em uma de suas últimas entrevistas (junho 2018), concedida a Wim Dierchxsens e a Walter Formento 4 ele traça um rápido diagnóstico sobre a crise capitalista. "É preciso saber que a sobrevivência do capitalismo é impossível sem crescimento e não vejo a possibilidade de outra fase do capitalismo com um crescimento sustentado. $\mathrm{O}$ que não significa que o regime vá morrer lenta e silenciosamente de morte natural. Ao contrário, o capitalismo senil se torna mais agressivo com contradições internas muito maiores. Para os povos, a crise sistêmica do capitalismo implica a crescente desigualdade na distribuição da renda e das riquezas dentro das sociedades, que é acompanhada de uma profunda estagnação, por um lado, e do aprofundamento da polarização global, por outro".

Samir Amin deixou para os intelectuais marxistas de todo o mundo um enorme legado com dezenas de livros, centenas de artigos, ensaios e entrevistas publicadas nas principais línguas do planeta. Entre seus últimos projetos estava a criação da Quinta Internacional dos Povos e Trabalhadores de todo o mundo, tarefa que cabe agora a seus amigos, discípulos e admiradores levar adiante, como uma atividade essencial não para "sair da crise capitalista, mas do capitalismo em crise".

O funeral de Samir Amin ocorrerá no dia $1^{\circ}$ de setembro, às 14:00, no cemitério Père Lachaise, em Paris. A cerimônia foi organizada e coordenada por Bernard Founou, Diretor de Pesquisa do FTM, Chérif Salif Sy, Diretor de Pesquisa do FTM e Lily Bayoumy, assistente do professor Samir Amin, atendendo às determinações da família. Desde o anúncio de seu falecimento Samir Amin recebeu homenagens das instituições que ele fundou ou contribuiu para a sua criação, de intelectuais, militantes e políticos de todo o mundo. Em seu funeral, familiares, amigos, colaboradores e intelectuais prestarão sua última homenagem. No dia de sua morte Samia Zennadi, de Argel, escreveu: "Uma estrela acaba de subir ao céu e o céu acaba de cair sobre minha cabeça, mas prometo, a luta continua camarada”.

\section{Paulo Nakatani}

\footnotetext{
4 AMIN, Samir. [Entrevista cedida a] Wim Dierckxsens e Walter Formento. Observatorio Internacional de la Crisis, 7 jun. 2018. Publicada em 14 de agosto de 2018. http://www.observatoriodelacrisis.org/2018/o8/entrevista-de-walter-formento-y-wim-dierckxens-a-samiramin-junio-2018/. Acesso em: 15 ago. 2018.
}

Argum., Vitória, v. 10, n. 2, p. 4-6, maio./ago. 2018. 